\title{
MH84 improves mitochondrial dysfunction in a mouse model of early Alzheimer's disease
}

\author{
Maximilian Pohland', Maren Pellowska², Heike Asseburg ${ }^{1,3}$, Stephanie Hagl ${ }^{1}$, Martina Reutzel ${ }^{3}$, Aljoscha Joppe $^{1}$,
} Dirk Berressem ${ }^{1}$, Schamim H. Eckert ${ }^{1}$, Mario Wurglics ${ }^{2}$, Manfred Schubert-Zsilavecz ${ }^{2}$ and Gunter P. Eckert ${ }^{3 *}$

\begin{abstract}
Background: Current approved drugs for Alzheimer's disease (AD) only attenuate symptoms, but do not cure the disease. The pirinixic acid derivate MH84 has been characterized as a dual gamma-secretase/proliferator activated receptor gamma (PPARY) modulator in vitro. Pharmacokinetic studies in mice showed that MH84 is bioavailable after oral administration and reaches the brain. We recently demonstrated that MH84 improved mitochondrial dysfunction in a cellular model of AD. In the present study, we extended the pharmacological characterization of MH84 to 3-month-old Thy-1 AßPP $P_{S L}$ mice (harboring the Swedish and London mutation in human amyloid precursor protein (APP)) which are characterized by enhanced ABPP processing and cerebral mitochondrial dysfunction, representing a mouse model of early AD.
\end{abstract}

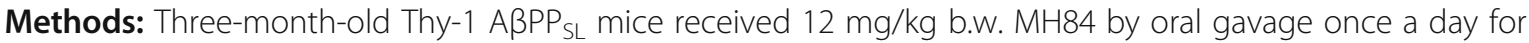
21 days. Mitochondrial respiration was analyzed in isolated brain mitochondria, and mitochondrial membrane potential and ATP levels were determined in dissociated brain cells. Citrate synthase (CS) activity was determined in brain tissues and MitoTracker Green fluorescence was measured in HEK293-AßPPwt and HEK293-AßPPsw cells. Soluble $A \beta_{1-40}$ and $A \beta_{1-42}$ levels were determined using ELISA. Western blot analysis and qRT-PCR were used to measure protein and mRNA levels, respectively.

Results: MH84 reduced cerebral levels of the $\beta$-secretase-related C99 peptide and of A $\beta 40$ levels. Mitochondrial dysfunction was ameliorated by restoring complex IV (cytochrome-c oxidase) respiration, mitochondrial membrane potential, and levels of ATP. Induction of PPARY coactivator-1a (PGC-1a) mRNA and protein expression was identified as a possible mode of action that leads to increased mitochondrial mass as indicated by enhanced CS activity, OXPHOS levels, and MitoTracker Green fluorescence.

Conclusions: MH84 modulates $\beta$-secretase processing of APP and improves mitochondrial dysfunction by a PGC1a-dependent mechanism. Thus, MH84 seems to be a new promising therapeutic agent with approved in-vivo activity for the treatment of $A D$.

Keywords: Alzheimer's disease, Mitochondrial dysfunction, PPAR gamma activator, PGC-1 alpha, APP processing, Amyloid-beta

* Correspondence: gunter.eckert@ernaehrung.uni-giessen.de

${ }^{3}$ Institute of Nutritional Sciences, Justus-Liebig-University, Giessen, Germany

Full list of author information is available at the end of the article

(c) The Author(s). 2018 Open Access This article is distributed under the terms of the Creative Commons Attribution 4.0 International License (http://creativecommons.org/licenses/by/4.0/), which permits unrestricted use, distribution, and reproduction in any medium, provided you give appropriate credit to the original author(s) and the source, provide a link to the Creative Commons license, and indicate if changes were made. The Creative Commons Public Domain Dedication waiver (http://creativecommons.org/publicdomain/zero/1.0/) applies to the data made available in this article, unless otherwise stated. 


\section{Background}

Alzheimer's disease (AD) is an age-related neurodegenerative disease and the primary cause for dementia in the elderly which represents a growing public health issue [1]. After a long prodromal phase, AD manifests itself clinically by a progressive cognitive decline followed by gradual personality changes [2]. Currently, there is no proven disease-modifying treatment available [3]. Interventions with current approved drugs, if started early enough, may at best temporarily slow down the progression but cannot impede dementia [4]. Thus, new therapeutic strategies are in the focus of drug discovery programs $[5,6]$. Neuropathological hallmarks of AD are extracellular amyloid plaques and intracellular neurofibrillary tangles [7, 8]. Amyloid plaques are composed of beta-amyloid $(\mathrm{A} \beta)$ protein, processed from the beta-amyloid precursor protein $(\mathrm{A} \beta \mathrm{PP})$ by initial $\beta$-secretase cleavage resulting in peptide C99. Subsequent cleavage of C99 by the $\gamma$-secretase complex results in the formation of $A \beta$ species of different lengths ranking from $A \beta 39$ to $A \beta 43$ [9]. $\beta$-Secretase, $\gamma$ secretase, and $A \beta$ itself were identified as pharmacological targets [10]. Peroxisome proliferator-activated receptor gamma (PPAR $\gamma$ ) represents another target for AD treatment [11-13]. A small pilot study that tested PPAR $\gamma$ agonist pioglitazone in patients with mild $\mathrm{AD}$ accompanied with type II diabetes exhibited cognitive and functional improvements [14]. Another preliminary study with rosiglitazone also showed preserved cognition in patients with early AD [15]. However, a large randomized clinical trial failed to show clinical efficacy of rosiglitazone in AD. In this trial, also no treatment difference in cognitive testing was detected for the competitor donepezil [16].

Beside its effects on $\mathrm{A} \beta \mathrm{PP}$ processing and $\mathrm{A} \beta$-mediated cell death, including reduced BACE1 expression and transcription, decreased BACE1 promoter activity, and a clearance mechanism for $A \beta$ [17-19], PPAR $\gamma$ agonists provide neuroprotection by improving mitochondrial dysfunction in models of neurodegenerative diseases [20, 21]. As an early event in AD pathogenesis [22, 23] mitochondrial dysfunction contributes to an impairment of the energy metabolism, defects in key respiratory enzyme activity/function, accumulation/generation of mitochondrial reactive oxidative species (ROS), induction of apoptosis, and altered mitochondrial biogenesis and dynamics [24, 25]. These observations led to the hypothesis that impaired mitochondrial function, associated with reduced energy metabolism and enhanced oxidative stress as well as synaptic dysfunction, represents a common final pathway of all specific (genetic) and nonspecific risk factors for the development of $\mathrm{AD}[22,26,27]$. This concept was put forward in the "mitochondrial cascade hypothesis" first proposed more than 10 years ago by Swerdlow et al. [28, 29]. This concept suggests that mitochondria at least mediate or possibly even initiate pathologic molecular cascades in $\mathrm{AD}$ [30].
Peroxisome proliferator-activated receptor-gamma coactivator alpha $(\mathrm{PGC}-1 \alpha)$ is a nuclear factor that regulates mitochondrial biogenesis in response to diverse environmental stimuli [31]. PGC-1 $\alpha$ has been associated with $\mathrm{AD}$ [32] and PGC-1 $\alpha$ messenger RNA expression was reported to be significantly decreased as a function of progression of clinical dementia in the AD brain [33]. It has been reported that PGC-1 $\alpha$ could protect cells against oxidative stress and reduce mitochondrial dysfunction [32].

The pirinixic adic derivate MH84 (ethyl 2-(4,6-bis(4-(trifluoromethyl)-phenethoxy)pyrimidin-2-yl-thio)hexanoate) (Fig. 1) was developed from the optimization of a novel structural class of dual $\gamma$-secretase/PPAR $\gamma$ modulators $[12,34]$. Pharmacokinetic properties of MH84 were investigated after oral administration of a single dose of $12 \mathrm{mg} / \mathrm{kg}$ b.w. in C57-Bl/6 mice and published previously (Table 1) [35]. In brain tissue a constant level of 300 to a maximum $320.64 \mathrm{ng} / \mathrm{g}$ was found after 1.5-6 hours [35]. We recently demonstrated that MH84 improved mitochondrial dysfunction in a cellular model of $\mathrm{AD}$ [36]. In the present study, we extended the pharmacological characterization of MH84 to 3-month-old Thy-1 $\mathrm{A} \beta \mathrm{PP}_{\mathrm{SL}}$ mice which are characterized by enhanced $\mathrm{A} \beta \mathrm{PP}$ processing and cerebral mitochondrial dysfunction, representing a mouse model of early $\mathrm{AD}[37,38]$.

\section{Methods \\ Chemicals}

Unless otherwise stated, chemicals were obtained from Sigma-Aldrich (Taufkirchen, Germany). MH84 (ethyl 2-(4,6-bis(4-(trifluoromethyl)phenethoxy)pyrimidin-2yl-thio)hexanoate) was synthesized according to literature procedures [12]. Analytical NMR data of the batch used for the current study are as follows (see also Additional file 1: Figure S1):

${ }^{1} \mathrm{H}-\mathrm{NMR}$ (300.13 MHz, (CD3)2SO): $\delta=0.78-0.83(\mathrm{t}$, $3 \mathrm{H}, J=7.1 \mathrm{~Hz}, \mathrm{Bu}-\mathrm{CH} 3), 1.22-1.37(\mathrm{~m}, 4 \mathrm{H}, \mathrm{Bu}-\mathrm{CH} 2)$,

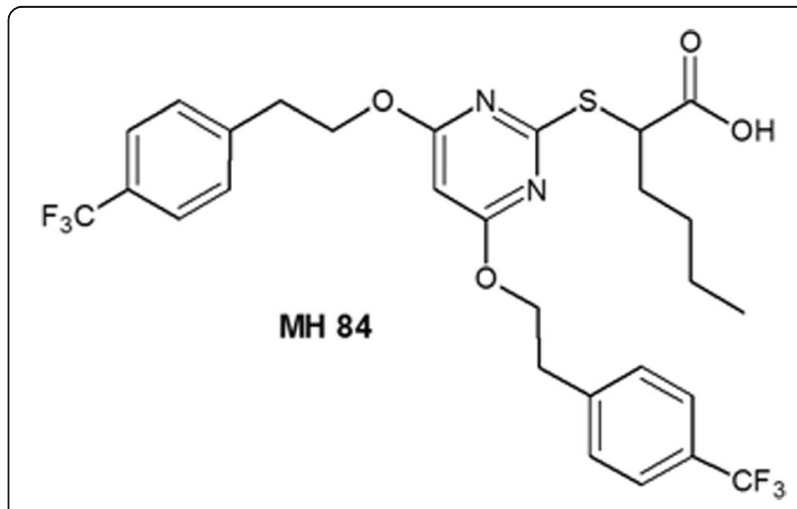

Fig. 1 Molecular structure of MH84 (ethyl 2-(4,6-bis(4(trifluoromethyl)phenethoxy)pyrimidin-2-yl-thio)hexanoate) [12] 
Table 1 Pharmacokinetic parameters of MH84

\begin{tabular}{lr}
\hline Parameter & Value \\
\hline$C_{\max }(\mu \mathrm{g} / \mathrm{g}$ plasma) & 10.90 \\
$T_{\max }(\mathrm{h})$ & 3.00 \\
$\mathrm{AUC}_{48 \mathrm{~h}}(\mu \mathrm{g} \mathrm{h} / \mathrm{ml})$ & 89.58 \\
$T_{1 / 2}(\mathrm{~h})$ & 3.24 \\
$\mathrm{CL}(\mathrm{ml} / \mathrm{min} / \mathrm{kg})$ & 2.23 \\
$\mathrm{Vd}(\mathrm{L} / \mathrm{kg})$ & 0.63
\end{tabular}

Plasma levels of MH84 were determined using HPCL after single oral gavage of $12 \mathrm{mg} / \mathrm{kg} \mathrm{MH84}$. The following pharmacokinetic parameters were adopted from our previous publication (for details, please refer to Pellowska et al. [35]):

$C_{\text {max }}$, maximum concentration; $T_{\max }$ time to reach $C_{\text {max }} ; \mathrm{AUC}_{48 \mathrm{~h}}$, area under the curve until $48 \mathrm{~h} ; T_{1 / 2}$, half-life time; $\mathrm{CL}$, clearance; $\mathrm{Vd}$, volume of distribution MH84 ethyl 2-(4,6-bis(4-(trifluoromethyl)phenethoxy)pyrimidin-2-yl-thio)hexanoate

1.74-1.92 (m, 2H, Bu-CH2), 3.06-3.11 (t, 4H, J= $6.6 \mathrm{~Hz}, \mathrm{Ph}-\mathrm{CH} 2), 4.27-4.30(\mathrm{t}, 1 \mathrm{H}, J=7.1 \mathrm{~Hz}, \mathrm{~S}-\mathrm{CH})$, 4.48-4.53 (t, 4H, J=6.6 Hz, Pyr-O-CH2), 5.87 (s, $1 \mathrm{H}$, Pyr-CH), 7.49-7.52 (d, 4H, J=8.0 Hz, Ph-C2/6), 7.63$7.66(\mathrm{~d}, 4 \mathrm{H}, J=8.0 \mathrm{~Hz}, \mathrm{Ph}-\mathrm{C} 3 / 5), 12.82(\mathrm{~s} / \mathrm{br}, 1 \mathrm{H}$, $\mathrm{COOH}) .{ }^{13} \mathrm{C}-\mathrm{NMR}$ (75.44 MHz, (CD3)2SO): $\delta=13.64$ (Bu-CH3), 21.67 (Bu-CH2), 28.92 (Bu-CH2), 30.91 (BuCH2), 34.16 (2C, Ph-CH2), 47.46 (S-CH), 66.54 (2C, Pyr-OCH2), 85.97 (Pyr-C5), 124.99 (4C, Ph-C3/5), 125.14-127.74 (2C, -CF3), 129.69 (4C, Ph-C2/6), 143.06 (2C, Ph-C1), 168.95 (Pyr-C2), 169.97 (2C, Pyr-C4/6), 172.23 (COOH). MS (ESI): $m / e=601.4(\mathrm{M}-1)$. Anal. $\left(\mathrm{C}_{28} \mathrm{H}_{28} \mathrm{~F}_{6} \mathrm{~N}_{2} \mathrm{O}_{4} \mathrm{~S}\right.$ (602.17)) C, H, N, S: ber, C 55.81, H 4.68, N 4.65, S 5.32; gef, $\mathrm{C} 56.10, \mathrm{H} 4.86, \mathrm{~N} 4.40, \mathrm{~S} 5.40$; Abw, C 0.29 , H $0.18, \mathrm{~N} 0.25$, S 0.08 .

\section{Animals and treatment}

Twenty-two C57BL/6 mice at the age of 3 months bearing the human Swedish (S: KM595/596NL) and London (L: V717I) mutations in the 751 amino acid form of human amyloid-beta precursor protein (A $\beta P P)$ under control of a murine Thy- 1 promoter were randomly divided into two groups of 11 Thy- $1 \mathrm{~A} \mathrm{PP}_{\mathrm{SL}}$ mice (Thy-1 $\mathrm{A} \beta \mathrm{PP}_{\mathrm{SL} \text { (control) }}$ and Thy-1 A $\mathrm{PP}_{\mathrm{SL} \text { (MH84) }}$ ) [39]. A number of 11 wild-type littermate animals were used as nontransgenic controls. Each group consisted of six females and five males. All animals were genotyped by tail biopsies and polymerase chain reaction before and after the experiments (data not shown). Animals were housed according to the German guidelines for animal care with access to water and food ad libitum. They were maintained on a 12-h light/dark cycle. Thy-1 A $\beta P_{\mathrm{SL}}$ (MH84) mice received $12 \mathrm{mg} / \mathrm{kg}$ b.w. MH84 by oral gavage once a day for 21 days. MH84 was diluted in polyethylene glycol 400 (PEG400). Control groups received an equal amount of PEG400. Health was assessed daily and PEG400 had no adverse effects. The mice were sacrificed by decapitation after cervical dislocation and the brains were quickly dissected on ice after removal of the cerebellum, the brain stem, and the olfactory bulb. All experiments were carried out by individuals with appropriate training and experience according to the requirements of the Federation of European Laboratory Animal Science Associations and the European Communities Council Directive (Directive 2010/63/EU). Experiments were approved by the regional authority (Regierungspraesidum Darmstadt; \#V54-19 c 20/15-FU_K_5003).

\section{Preparation of isolated brain mitochondria}

Brain mitochondria were isolated from one hemisphere as reported previously [40]. Briefly, the cerebrum was homogenized using a potter equipped with a Teflon pistil in $2 \mathrm{ml}$ mitochondrial respiration medium (MiR05) containing a protease inhibitor cocktail (PI, complete; Roche, Mannheim, Germany). The resulting homogenate was centrifuged to remove the nuclei and other cell debris $\left(1400 \times g, 7 \mathrm{~min}, 4^{\circ} \mathrm{C}\right)$. The low-speed centrifugation step was repeated once (for $3 \mathrm{~min}$ ) with the supernatant followed by a high-speed centrifugation step $(10.000 \times g$, $5 \mathrm{~min}, 4^{\circ} \mathrm{C}$ ) to collect a pellet enriched in mitochondria. This pellet was resuspended in $1 \mathrm{ml}$ ice-cold MiR05 + PI and centrifuged $\left(1400 \times g, 3 \mathrm{~min}, 4{ }^{\circ} \mathrm{C}\right)$. The supernatant was centrifuged once again at high speed $(10.000 \times g$, $5 \mathrm{~min}, 4{ }^{\circ} \mathrm{C}$ ) to obtain the mitochondrial fraction. The resulting pellet was then dissolved in $250 \mu \mathrm{l} \mathrm{MiR05+PI}$. The obtained solution of isolated mitochondria was then used for high-resolution respirometry $(80 \mu \mathrm{l})$. The remaining solution was immediately frozen in liquid nitrogen for citrate synthase (CS) activity $(120 \mu \mathrm{l})$ and protein determinations $(50 \mu \mathrm{l})$ and stored at $-80{ }^{\circ} \mathrm{C}$.

\section{High-resolution respirometry}

Mitochondrial respiration was analyzed as reported previously [40]. Briefly, $80 \mu \mathrm{l}$ of isolated mitochondria in MiR05 were injected into a chamber of the Oxygraph$2 \mathrm{k}$ at $37{ }^{\circ} \mathrm{C}$ (Oroboros, Innsbruck, Austria), and a complex protocol (developed by Erich Gnaiger, Innsbruck, Austria) containing different substrates, uncouplers, and inhibitors was carried out [41]. The capacity of oxidative phosphorylation (OXPHOS) was determined with complex I-related substrates $\left(\mathrm{CI}_{\mathrm{OxPHOS}}\right)$ pyruvate $(5 \mathrm{mM})$, malate $(2 \mathrm{mM})$, and adenosine 5 '-diphosphate (ADP) (2 $\mathrm{mM})$ followed by addition of succinate $(10 \mathrm{mM}, \mathrm{CI}+$ $\left.\mathrm{II}_{\mathrm{OXPHOS}}\right)$. Mitochondrial integrity was examined via addition of cytochrome c $(10 \mu \mathrm{M})$. Subsequently, oligomycin $(2 \mu \mathrm{g} / \mathrm{ml})$ was added to reveal leak respiration (leak omy). The maximum capacity of the electron transfer system (ETS) was achieved by titration of carbonyl cyanide $p$-(trifluoromethoxy) phenylhydrazone (FCCP). Complex II respiration in the noncoupled state $\left(\mathrm{CII}_{\mathrm{ETS}}\right)$ was measured after adding rotenone $(0.5 \mu \mathrm{M})$ into the chambers. Residual oxygen consumption (ROX) was determined after inhibition of complex III by addition of antimycin A 
$(2.5 \mu \mathrm{M})$ and was subtracted from all respiratory parameters. Cyclooxygenase activity $\left(\mathrm{CIV}_{\mathrm{ETS}}\right)$ was measured after by applying $0.5 \mathrm{mM}$ tetramethylphenylenediamine (TMPD) as an artificial substrate of CIV and $2 \mathrm{mM}$ ascorbate to keep TMPD in the reduced state. The autoxidation rate was determined after the addition of sodium azide $(\geq 100 \mathrm{mM})$. For data analysis, DatLab 5.1.1.7 software (Oroboros) was used. Data of mitochondrial respiration were normalized to CS activity.

\section{Preparation of dissociated brain cells for in-vitro studies}

Dissociated brain cells (DBC) were isolated from one hemisphere as reported previously [37, 40]. Briefly, after preparation, DBC were resuspended in $4.5 \mathrm{ml}$ DMEM without supplements. The suspension was seeded in $250-\mu \mathrm{l}$ aliquots into a 24 -well plate with 12 replicates (for measurement of mitochondrial membrane potential) or in 50- $\mu \mathrm{l}$ aliquots into a 96 -well plate with 12 replicates (for measurement of ATP level). Afterward the cells were maintained for $3 \mathrm{~h}$ at $37{ }^{\circ} \mathrm{C}$ in a humidified incubator, gassed with $5 \% \mathrm{CO}_{2}$. A 1-ml aliquot of the remaining cell suspension was collected and immediately frozen at $-80{ }^{\circ} \mathrm{C}$ for protein determination.

\section{Determination of mitochondrial membrane potential}

The potential of the inner mitochondrial membrane (MMP) was determined in DBC as described previously using the cell-permeable fluorescent dye rhodamine 123 (R123) with a VICTOR ${ }^{\mathrm{m}}$ X3 2020 Multilabel Counter (Perkin Elmer, Rodgau, Germany) [40].

\section{Determination of ATP levels}

ATP levels were determined in DBC using the ViaLight Plus bioluminescence assay according to the manufacturer's instructions (Lonza, Walkersville, USA) with a VICTOR $^{\text {tw }}$ X3 Multilabel Counter (Perkin Elmer), as described previously $[37,40]$.

\section{Citrate synthase activity}

CS activity was determined in isolated mitochondria as described previously [40]. A frozen subsample of the isolated mitochondria dissolved in MiR05 was thawed on ice. A reaction medium containing $100 \mu \mathrm{l}$ of $0.1 \mathrm{mM} \mathrm{5,5^{ \prime } -}$ dithiobis-(2-nitrobenzoic acid) (DTNB), $25 \mu \mathrm{l}$ of $10 \%$ Triton X-100, $50 \mu \mathrm{l}$ of $10 \mathrm{mM}$ oxaloacetate, $25 \mu \mathrm{l}$ of $12.2 \mathrm{mM}$ acetyl coenzyme A, and $790 \mu \mathrm{l}$ purified water was mixed and preheated at $30{ }^{\circ} \mathrm{C}$ for $5 \mathrm{~min}$. Subsequently, $10 \mu \mathrm{l}$ of the isolated mitochondria was added to the reaction medium and transferred into a $10-\mathrm{mm}$ quartz cuvette (Hellma Analytics, Muellheim, Germany). CS activity was assessed at $412 \mathrm{~nm}$ using a GENESYS 5 spectrophotometer (Spectronic via Thermo Fisher Scientific, Waltham, MA, USA) and normalized to protein content. Measurements were performed in duplicate.

\section{Cell culture}

Human embryonic kidney (HEK) 293 cells containing hu-

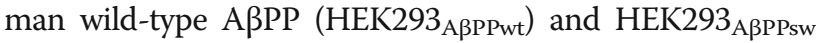
cells transfected with DNA constructs harboring human mutant A $\beta P P$ (A $\beta P P s w, K M 670 / 671 N L)$ gene were cultured in Dulbecco's modified Eagle's medium (DMEM) supplemented with $10 \%$ heat-inactivated fetal calf serum, 50 units/ml penicillin, $50 \mu \mathrm{g} / \mathrm{ml}$ streptomycin, and $400 \mu \mathrm{g} /$ $\mathrm{ml}$ Geniticin (G418). Both cell lines were maintained in a humified incubator, gassed with $5 \% \mathrm{CO}_{2}$ at $37{ }^{\circ} \mathrm{C}$ as described previously [36]. The HEK293 ${ }_{\text {A PPPwt }}$ cell line was a kind gift received from Prof. Christian Haass, Munich, Germany.

\section{MitoTracker Green}

MitoTracker Green (MTG) measurements were performed as described previously [42]. Briefly, 2 days before the measurement 100,000 cells/well of HEK293 ${ }_{\text {A PPPwt }}$ cells and HEK293 ${ }_{\mathrm{A} \beta \mathrm{PPsw}}$ cells were seeded into a 24-well plate. On the next day cell medium was incubated for $24 \mathrm{~h}$ with $0.1 \mu \mathrm{M}$ MH84. For solvent control DMSO (0.05\%) was used. Afterward the cells were washed with $500 \mu$ l Hank's Balanced Salt Solution buffer (HBSS) ( $\mathrm{pH} 7.4,37^{\circ} \mathrm{C}$ supplemented with $\mathrm{Mg}^{2+}, \mathrm{Ca}^{2+}$ and HEPES) and spiked with $1 \mu \mathrm{M}$ MTG (Invitrogen, Camarillo, USA) and incubated for $60 \mathrm{~min}$. After adding fresh HBSS buffer to the cells, fluorescence was measured at an excitation wavelength of $490 \mathrm{~nm}$ and an emission wavelength of $516 \mathrm{~nm}$ in a VICTOR $^{\text {Tm }}$ X3 Multilabel Counter (Perkin Elmer). When comparing HEK293 ${ }_{\text {A PPPwt }}$ cells and HEK293 ${ }_{\text {A PPPsw }}$ cells, fluorescence values were normalized to protein content.

\section{Determination of soluble $A \beta$}

The content of soluble $A \beta_{1-40}$ and $A \beta_{1-42}$ in supernatants was detected by specific solid phase sandwich enzymelinked immunosorbent assays (ELISA; Life Technologies, Carlsbad, CA, USA) following the instructions of the supplier. Brain material was homogenized in 10 times the amount of phosphate-buffered saline containing a protease inhibitor cocktail. After homogenization, samples were centrifuged $\left(15,000 \times g, 30 \mathrm{~min}, 4{ }^{\circ} \mathrm{C}\right)$ and the supernatants were transferred to a fresh reaction vessel and stored at $-80{ }^{\circ} \mathrm{C}$ prior to analysis. Total protein content was

Table 2 Oligonucleotide primer sequences

\begin{tabular}{llll}
\hline Primer & Sequence & $\begin{array}{l}\text { Accession } \\
\text { number }\end{array}$ & $\begin{array}{l}\text { Product } \\
\text { size (bp) }\end{array}$ \\
\hline B2M & 5'-GGC CTG TAT GCT ATC CAG AA-3' & NM_009735.2 & 198 \\
& 5'-GAA AGA CCA GTC CTT GCT GA-3' & & \\
PGK1 & 5'-GCA GAT TGT TTG GAA TGG TC-3' & NM_008828.2 & 185 \\
& 5'-TGC TCA CAT GGC TGA CTTT TA-3' & & \\
BACE1 & Confidential & NC_000075.6 & 65 \\
PGC1a & 5'-TGT CAC CAC CGA AAT CCT-3' & NM_008904.2 & 124 \\
& 5'-CCT GGG GAC CTT GAT CTT-3' & & \\
\hline
\end{tabular}


determined using a Pierce $^{\mathrm{T \omega}}$ BCA Protein Assay Kit (Thermo Scientific, Rockford, IL, USA).

\section{Western blot analysis}

Western blot analysis was carried out in brain tissue homogenates as reported previously [36]. Briefly, brain samples were homogenized in lysis buffer. Total protein content was determined using a Pierce ${ }^{\mathrm{Tw}}$ BCA Protein Assay Kit (Thermo Scientific). Band analysis was performed using
ChemiDoc XRS system (BioRad, Munich, Germany). The following antibodies were used: full-length $A \beta P P$ (fl-A $\beta P P)$ and C-terminal fragments (CTFs) were detected using A $\beta P P$ C-Terminal Fragment (C1/6.1) antibody (SIG-39152; Covance, Princeton, NJ, USA). Detection of respiratory system complexes was carried out by MitoProfile Total OXPHOS Rodent WB Antibody Cocktail (ab110413; abcam, Cambridge, UK). As primary antibody for synaptic markers, Anti-BDNF (ab72439; abcam), Anti-GAP43
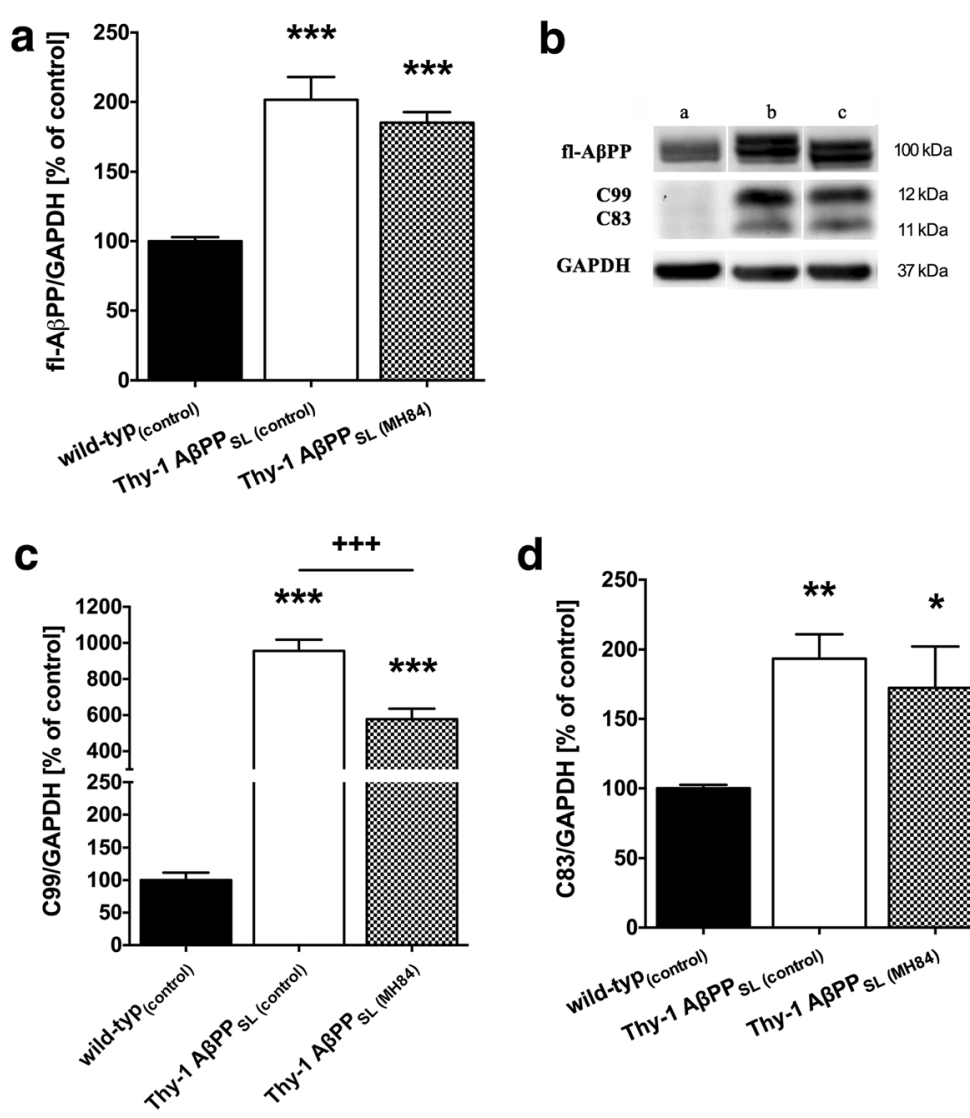

d
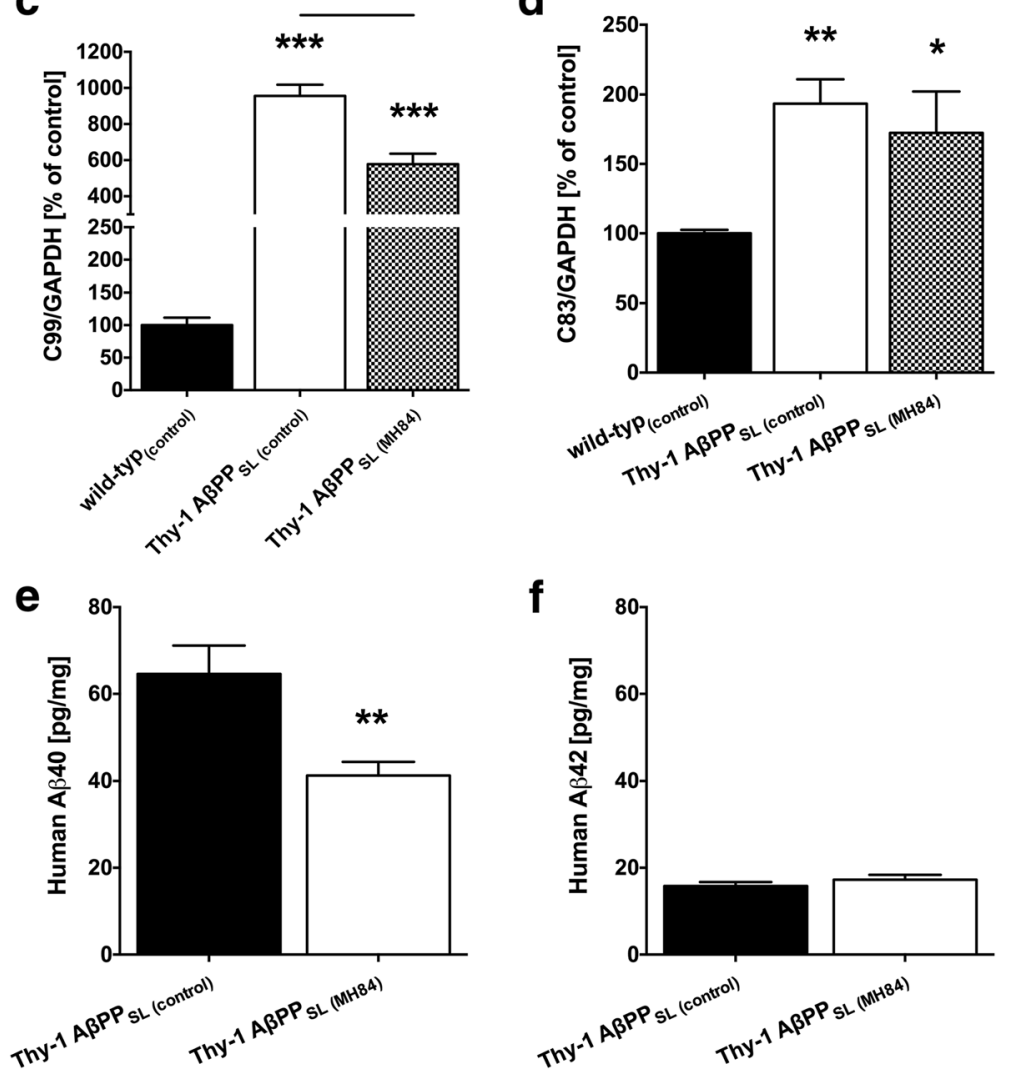

Fig. 2 Brain levels of full-length amyloid precursor protein (a, b fl-A $\mathrm{PPP}$ ) and its a-secretase and $\beta$-secretase cleavage products C83 and C99, respectively $(\mathbf{b}, \mathbf{c}, \mathbf{d}$ ) detected using western blot techniques. Data represent means \pm SEM from eight experiments; one-way ANOVA with Tukey's

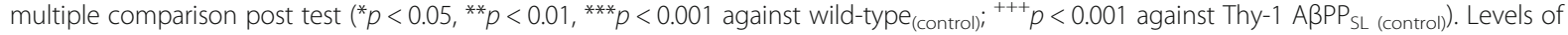
soluble human $\beta$-amyloid peptides (e A 440 and $\mathbf{f} A \beta 42$ ) were determined using ELISA. Data represent means \pm SEM. $N=11$ (six females, five males); Student's unpaired $t$ test (** $p<0.01$ against Thy-1 A $\beta P P_{S L}$ (control). A ${ }^{*}$ PP beta-amyloid precursor protein, A $\beta$ amyloid-beta 
(ab12274; abcam), and Anti-synaptophysin (ab32127; abcam) were used. To detect protein expression of PGC$1 \alpha$ in the brain, Anti-PGC-1 $\alpha$ antibody (ab106814; abcam) was used. Anti-tubulin antibody (ab6160; abcam) and Antiglyceraldehyde 3-phosphate dehydrogenase (GAPDH) antibody (MAB374; Merck Millipore, Darmstadt, Germany) were used to verify equal protein loading.

\section{Quantitative real-time PCR}

qRT-PCR measurements were carried out as described previously [42]. Briefly, total RNA was isolated from frozen brain tissues using the RNeasy Mini Kit (Qiagen, Hilden, Germany) according to the manufacturer's instructions. Maximum yield of RNA was obtained using $20 \mathrm{mg} / \mathrm{ml}$ Proteinase K (Carl Roth, Karlsruhe, Germany). RNA was quantified by measuring the absorbance at 260 nm using a NanoDrop ${ }^{\text {ta }}$ 2000c spectrophotometer (Thermo Fisher Scientific). Purity of RNA was assessed by the ratio of absorbance at $260 \mathrm{~nm}$ and $280 \mathrm{~nm}$. Firststrand cDNA was synthesized from $50 \mathrm{ng}$ total RNA using the iScript cDNA synthesis kit (BioRad) according to the manufacturer's instructions. Real-time PCR was performed using SYBR Green technology on a CFX96 Touch $^{\text {mi }}$ Real-Time PCR Detection System (BioRad). Target-specific primer pair reference genes PGK1 and B2M were purchased from biomol (Hamburg, Germany). Betasite A $\beta P P$ cleaving enzyme (BACE1) primer pairs were purchased from Bio-Rad Laboratories. PGC-1 $\alpha$ primer pairs were designed by biomers.net (Ulm, Germany) (Table 2).

Prior optimization was conducted for each set of primers, which consisted of determining optimal primer concentration and template concentration and verifying the efficiency of the amplification. To confirm the specificity of the amplification, the PCR product was subjected to melting curve analysis and agarose gel electrophoresis. PCR amplification was performed in duplicate in a total reaction volume of $10 \mu \mathrm{l}$. The reaction mix consisted of $2 \mu \mathrm{l}$ template, $5 \mu \mathrm{l}$ iTaq $^{\mathrm{Tm}}$ Universal SYBR $^{\circ}$ Green Supermix, and forward and reverse primers at the following concentrations: $50 \mathrm{nM}$ (PGC$1 \alpha), 200 \mathrm{nM}$ (BACE1), or $400 \mathrm{nM}$ (PGK1, B2M). After a 3-min activation of Taq polymerase, amplification was allowed to proceed for 46 cycles. Each cycle consisted of denaturation at $95{ }^{\circ} \mathrm{C}$ for $10 \mathrm{~s}$, annealing at $58{ }^{\circ} \mathrm{C}$ for $45 \mathrm{~s}$, and extension at $72{ }^{\circ} \mathrm{C}$ for $29 \mathrm{~s}$. BACE1 mRNA expression was performed in a two-step PCR amplification. After a 2-min activation of Taq polymerase, amplification was allowed to proceed for 40 cycles. Each cycle consisted of denaturation at $95{ }^{\circ} \mathrm{C}$ for $5 \mathrm{~s}$ and annealing and extension at $60{ }^{\circ} \mathrm{C}$ for $30 \mathrm{~s}$. The one-cycle melting curve consisted of heating from 65 to $95{ }^{\circ} \mathrm{C}$ by $0.5^{\circ} \mathrm{C}$ steps, with 5-s hold per step. Results were normalized to PGK1 and B2M as reference genes which are stably expressed in mouse brain [43]. Results were analyzed using the $2^{-\Delta \Delta \mathrm{Cq}}$ method with target-specific amplification efficiency.

\section{Statistical analysis}

All data are presented as means \pm SEM. For statistical analysis GraphPad Prism 5.03 software (GraphPad Software, Inc., La Jolla, CA, USA) was used. For the examination of statistical significant differences between two groups a two-sided, unpaired Student's $t$ test and for multiple comparisons a one-way ANOVA with Tukey's multiple comparison post test or a two-way ANOVA followed by
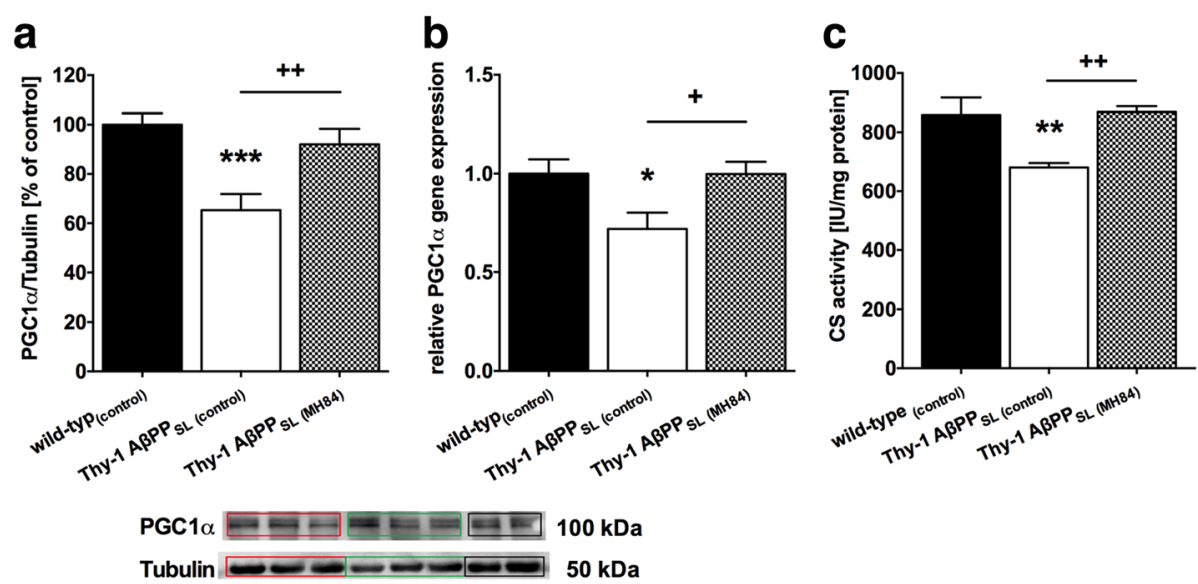

Fig. 3 Brain levels of PGC-1a protein (a) and mRNA (b). Representative western blot assays are included in lower part of a. Band of PGC-1a was located in second place at $100 \mathrm{kDa}$. Tubulin used as loading control. Expression levels of mRNA were normalized to PGK1 and B2M mRNA expression. Citrate synthase (CS) activity as a marker of mitochondrial content was determined in isolated brain mitochondria using a photometrical assay (c). Animals

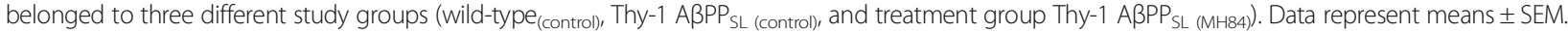

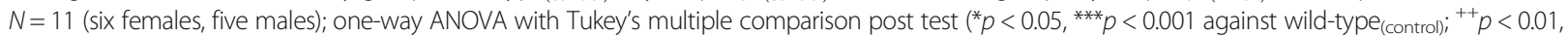
${ }^{+} p<0.05$ against Thy-1 ABPP ${ }_{S L}($ control)). PGC-1 a peroxisome proliferator-activated receptor- $\gamma$ coactivator alpha, AßPP beta-amyloid precursor protein 
Bonferroni post test was performed. $p<0.05, p<0.01$, and $p<0.001$ were considered statistically significant.

\section{Results}

MH84 decreased $\beta$-secretase cleavage and $A \beta 40$ levels Protein levels of full-length A $\beta P P$ (fl-A $\beta P P$ ) were increased in brains of Thy- $1 \mathrm{~A} \beta \mathrm{PP}_{\mathrm{SL}}$ mice (Fig. 2a, b).
Elevated protein levels of the $\beta$-secretase cleavage products C99 and C83 were also detected (Fig. 2b-d). Approximately 68 and $18 \mathrm{pg} / \mathrm{mg}$ of human $A \beta 40$ and $A \beta 42$ were determined in brain tissues of Thy- $1 \mathrm{~A} \beta \mathrm{PP}_{\mathrm{SL}}$ mice, respectively (Fig. 2e, f). Levels of soluble human $A \beta 40$ or A $\beta 42$ were not detectable in wild-type control mice (data not shown). Treatment with MH84 significantly
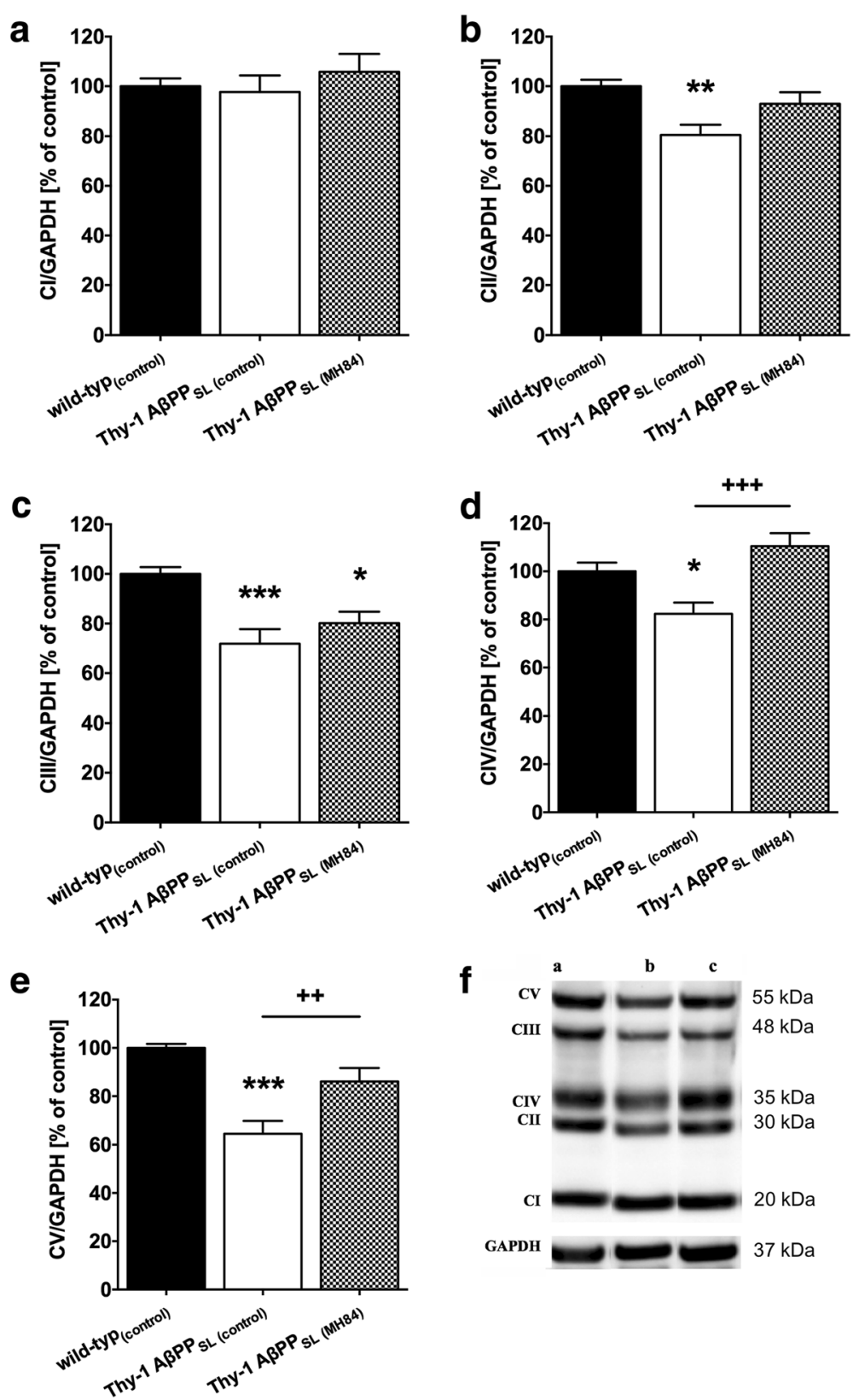

Fig. 4 Western blot analysis of mitochondrial respiration chain complexes (a Cl, b CII, c CIII, d CIV, e CV) in brain homogenate from wild-

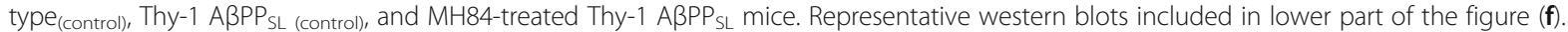
GAPDH was used as loading control. Data represent means \pm SEM. $N=11$ (six females, five males); one-way ANOVA with Tukey's multiple comparison post test $\left({ }^{* * *} p<0.001,{ }^{* *} p<0.01,{ }^{*} p<0.05\right.$ against wild-type $\left(\right.$ control) ${ }^{+++} p<0.001,{ }^{++} p<0.01$ against Thy- 1 A ${ }^{*} P_{S L}$ (control)). Cl complex I (NADH reductase), CII complex II (succinate dehydrogenase), CIII complex III (cytochrome-c reductase), CIV complex IV (cytochrome-c oxidase), CV complex $V\left(F_{1} / F_{0}\right.$-ATPase), AßPP beta-amyloid precursor protein 
decreased the $\beta$-secretase cleavage product $\mathrm{C} 99$ and levels of soluble human $A \beta 40$ in brain homogenates of Thy-1 A $\beta P_{\mathrm{SL}}$ mice (Fig. 2c, e). Expression of the $\beta$-site of APP cleaving enzyme (BACE1) significantly increased in Thy-1 $\mathrm{A} \beta \mathrm{PP}_{\mathrm{SL}}$ mice and administration of MH84 numerically but not significantly reduced BCAE1 mRNA levels (Additional file 2: Figure S2).

\section{MH84 enhanced PGC-1a expression, mitochondrial mass, and BDNF levels}

Protein and mRNA levels of PGC-1 $\alpha$ were significantly decreased in the brain of Thy-1 $\mathrm{A} \beta \mathrm{PP}_{\mathrm{SL}}$ mice (Fig. 3a, b). Since PGC-1 $\alpha$ represents one of the most important nuclear factors for the induction of mitogenesis [34], this finding might indicate a reduced mitochondrial mass in brains of Thy-1 A $\beta \mathrm{PP}_{\mathrm{SL}}$ mice. Accordingly, CS activity representing a robust mitochondrial mass marker [44] was also significantly decreased (Fig. 3c). Decreased protein levels of mitochondrial respiration complexes (CII$\mathrm{CV}$ ) further indicate a reduced mitochondrial mass in brains of Thy- $1 \mathrm{~A} \beta \mathrm{PP}_{\mathrm{SL}}$ mice (Fig. 4a-f). MH84 reversed protein and mRNA levels of PGC- $1 \alpha$ as well as of CS activity (Fig. 3a-c). Moreover, MH84 significantly enhanced protein levels of CIV and CV (Fig. 4d, e). Moreover, MH84 reversed the fluorescence of the mitochondrial mass marker MitoTracker Green (MTG) in HEK293A $\beta P P s w$ cells, which further indicated that MH84 enhanced mitochondrial content (Fig. 5). HEK293-AßPPsw cells represent a cellular AD model characterized by elevated $A \beta$ levels and mitochondrial dysfunction $[36,45,46]$.

A recent report related reduced PGC- $1 \alpha$ levels to reduced expression of brain-derived neurotrophic factor (BDNF) [47]. Western blot analysis show significantly decreased brain levels of BDNF (Additional file 2: Figure S2). The synaptic marker protein growth associated protein 43 (GAP43) was also significantly reduced in brain samples of Thy-1 APP $\mathrm{SL}_{\mathrm{SL}}$ mice, but not of synaptophysin (Additional file 2: Figure S2). MH84 administration increased BDNF protein levels but had no effects on the synaptic marker proteins GAP43 and synaptophysin (Additional file 3: Figure S3).

\section{MH84 reversed mitochondrial dysfunction}

The complexes of the mitochondrial respiration chain (complex I, NADH reductase (CI); complex II, succinate dehydrogenase (CII); complex III, cytochrome-c reductase (CIII); complex IV, cytochrome-c oxidase (CIV)) build up a proton gradient at the inner mitochondrial membrane. The resulting membrane potential (MMP) finally represents the driving force for complex $\mathrm{V}$ of the mitochondrial respiration chain $\left(\mathrm{F}_{1} / \mathrm{F}_{0}\right.$-ATPase $\left.(\mathrm{CV})\right)$ that produces ATP. Respiration of CIV of the mitochondrial respiration chain was significantly decreased in

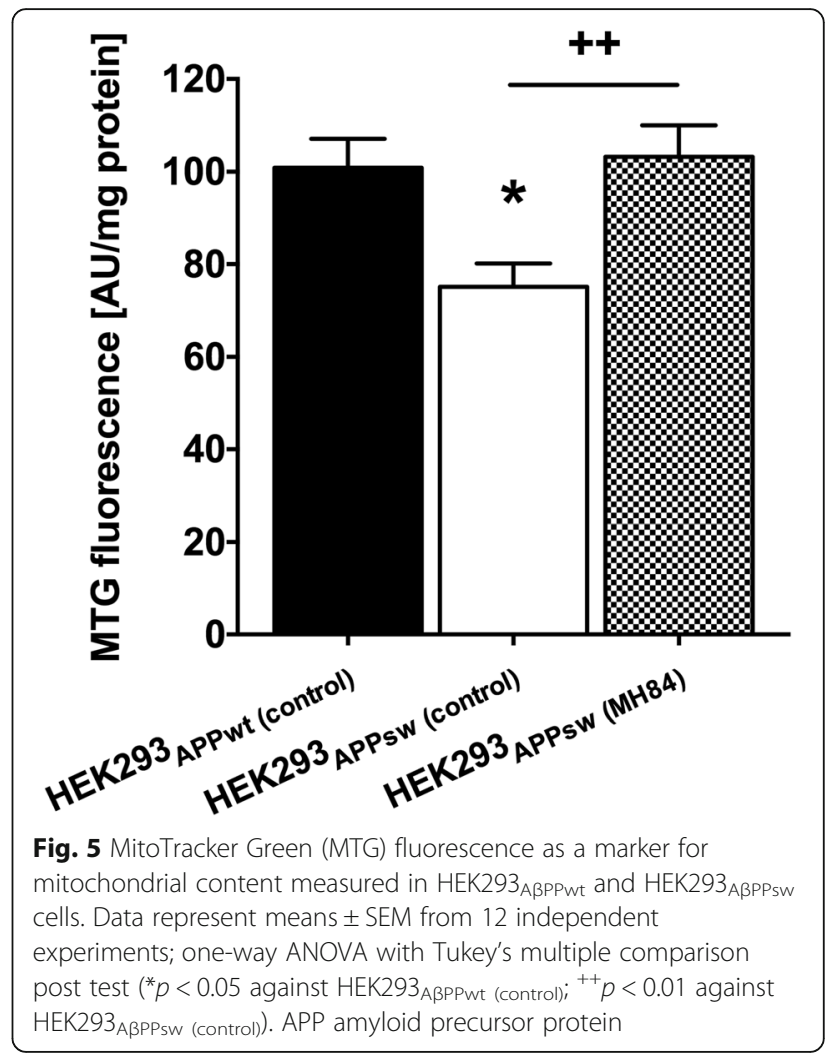

mitochondria isolated from brains of Thy-1 $\mathrm{A} \beta \mathrm{PP} \mathrm{SL}_{\mathrm{SL}}$ mice (Fig. 6a). Consequently, MMP and ATP levels were significantly decreased in DBC isolated from Thy- 1 $\mathrm{A} \beta \mathrm{PP}_{\mathrm{SL}}$ mice (Fig. 6b, c). All three parameters were reversed after MH84 treatment (Fig. 6a-c).

\section{Discussion}

In this study, the effects of MH84 on mitochondrial dysfunction were investigated in 3-month-old transgenic Thy- $1 \mathrm{~A} \beta \mathrm{PP}_{\mathrm{SL}}$ mice representing a model of early $\mathrm{AD}$ [37]. Since these mice develop typical $A \beta$ plaques at the age of 6 months [39], we focused on soluble $A \beta$ levels and confirm moderately elevated cerebral content of $A \beta$ at an age of 3 months [39]. Moreover, levels of fl-A $\mathrm{PPP}$ and $C 99$ were enhanced in brains of these mice as well. There is evidence that accumulation of $\mathrm{A} \beta, \mathrm{fl}-\mathrm{A} \beta \mathrm{PP}$, and C99, which are able to enter mitochondria and interact with mitochondrial proteins, might result in impaired mitochondrial function and energy metabolism [27, 48-52]. However, mitochondrial dysfunction might also be a result of lower levels of PGC-1 $\alpha[32,53]$. There is convincing evidence for a link between PGC- $1 \alpha$ and AD [32, 47], and numerous studies demonstrated that the pharmacological targeting of particular nuclear receptors is beneficial in mouse models of AD (reviewed in [13]). Decreased levels of PGC- $1 \alpha$ have been reported in postmortem brain tissue of 


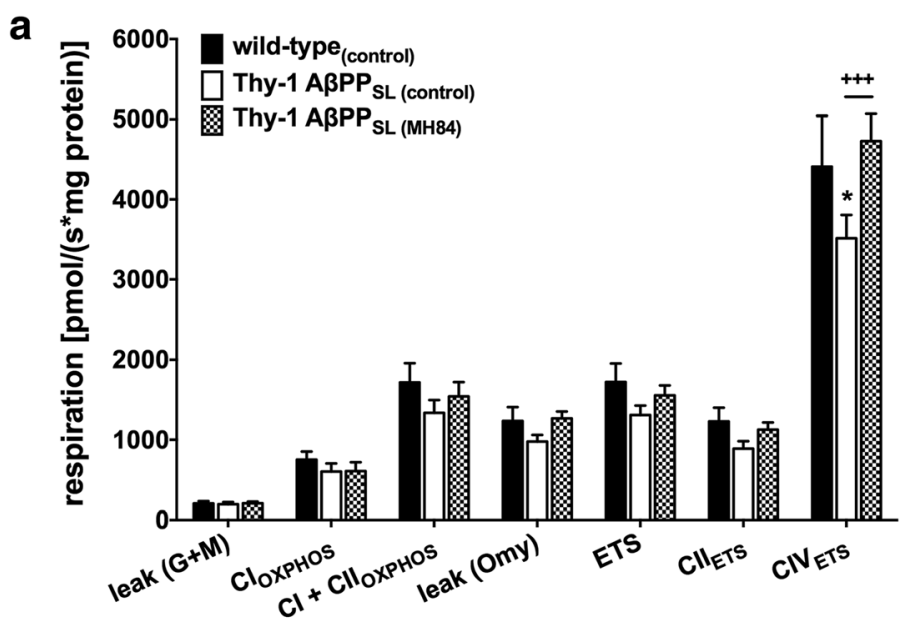

b

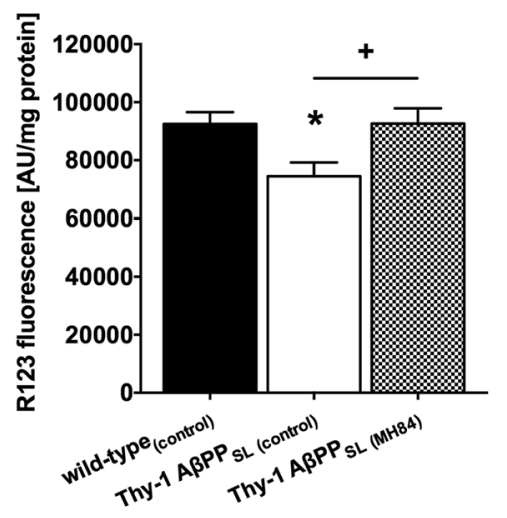

C

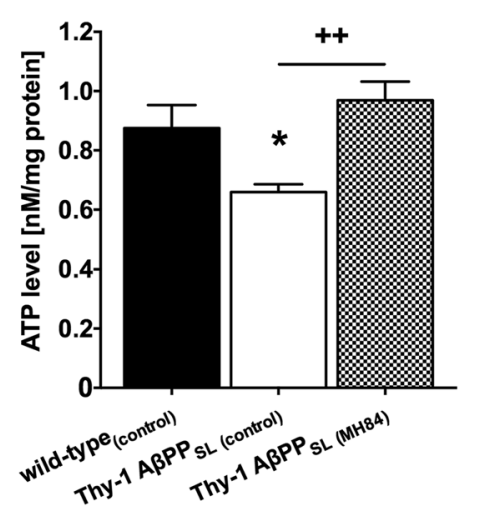

Fig. 6 Analysis of mitochondrial respiration of isolated brain mitochondria (a) performed using an Oxygraph-2 k system. Animals belonged to

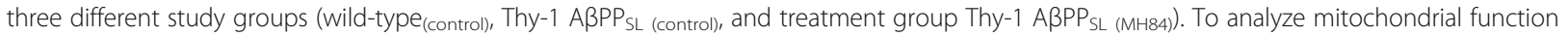
different substrates, uncouplers and inhibitors were added; for details please refer to Methods. Data represent means \pm SEM from 10 experiments; two-way ANOVA with Bonferroni post test ${ }^{*} p<0.05$ against wild-type $\left(\right.$ control); ${ }^{+++} p<0.001$ against Thy-1 AßPP $\mathrm{SL}$ (control)). Basal mitochondrial membrane potential (MMP; R123 fluorescence) (b) and ATP levels (c) of mitochondria measured in dissociated brain cells. MMP determined using R123 as fluorescence dye. ATP levels determined using a bioluminescence assay. Data represent means \pm SEM. $N=11$ (six females, five males); one-way ANOVA with Tukey's multiple comparison post test $\left({ }^{*} p<0.05\right.$ against wild-type $\left(\right.$ control); ${ }^{+} p<0.05,{ }^{++} p<0.01$ against Thy- 1 A PPP $P_{S L}$ (control)). $\mathrm{Cl}$ complex I (NADH reductase, CII complex II (succinate dehydrogenase), CIV complex IV (cytochrome-c oxidase), ETS electron transfer system, AßPP beta-amyloid precursor protein

AD patients [33] and in a ABPPswe/PS1de9 mouse model of $\mathrm{AD}$ [54]. PGC- $1 \alpha$ protein and mRNA levels were also found to be significantly decreased in the present study. PGC- $1 \alpha$ has been characterized as one of the main regulators of PPAR $\gamma$ and as an essential initiator for mitochondrial biogenesis and respiration $[55,56]$. Thus, decreased PGC- $1 \alpha$ levels might play a role for impaired mitochondrial biogenesis [57] and mitochondrial dysfunction [37]. Accordingly, we determined the activity of the mitochondrial marker enzyme CS, which has been reported as one of the best markers of mitochondrial mass [58]. In our study, CS activity was significantly reduced in mitochondria isolated from brains of Thy-1 A $\beta P_{\mathrm{SL}}$ mice, indicating reduced mitochondrial mass. This finding is in agreement with reduced PGC-1 $\alpha$ levels in brain tissue samples isolated from these mice. However, Hauptmann et al. [37] detected no differences in the mitochondrial content in brains of Thy-1 $\mathrm{A} \beta \mathrm{PP}_{\mathrm{SL}}$ mice using MitoTracker Green fluorescence and PCR. On the other hand, reduced complex IV activity, MMP, and ATP levels are in accordance with this earlier publication [37] and other reports on mouse models of AD [59-61].

Mice were treated for 21 days with $12 \mathrm{mg} / \mathrm{kg}$ body weight (b.w.) MH84 using oral gavage. Pharmacokinetic properties of MH84 were investigated previously and we reported a maximum brain concentration of $320.64 \mathrm{ng} / \mathrm{g}$ [35]. MH84 is a small molecule that has been characterized as a dual PPAR $\gamma$ agonist and $\gamma$-secretase modulator in vitro 
[12, 34, 62]. However, our in-vivo data indicated modulation of $\beta$-secretase rather than $\gamma$-secretase: Treatment with MH84 significantly decreased the $\beta$-secretase cleavage product $C 99$ and levels of soluble human $A \beta 40$ in brain homogenates of Thy-1 $\mathrm{A} \beta \mathrm{PP}_{\mathrm{SL}}$ mice.

The present study also shows that MH84 reversed mitochondrial dysfunction and PGC- $1 \alpha$ levels, decreased $\beta$-secretase processing of $\mathrm{A} \beta \mathrm{PP}$, and reduced levels of soluble $A \beta 40$ in brains of transgenic Thy- 1 $\mathrm{A} \beta \mathrm{PP}_{\mathrm{SL}}$ mice. These findings are in line with data for a cellular model of $\mathrm{AD}$ that we have been reported recently [36]. PGC- $1 \alpha$ regulates a large set of mitochondrial genes as an essential initiator for mitochondrial biogenesis and respiration $[55,56]$. Thus, increased CS activity and OXPHOS protein levels indicate that MH84 enhanced biogenesis of mitochondria by a PGC$1 \alpha$-dependent mechanism and thereby compensates for mitochondrial dysfunction in brains of Thy-1 $\mathrm{A} \beta \mathrm{PP}_{\mathrm{SL}}$ mice. Enhanced MitoTracker Green (MTG) fluorescence after incubation of HEK-A $\beta P P s w$ cells with MH84 further supports this hypothesis. MTG accumulates in mitochondria independently of the mitochondrial membrane potential and thus represents another suitable marker for the determination of mitochondrial content [63]. Katsouri et al. [19, 64] showed that PGC$1 \alpha$ reduces $A \beta$ generation through a PPAR $\gamma$-dependent mechanism and demonstrated recently that PGC- $1 \alpha$ transfer reduces neuronal loss and $A \beta$ generation by reducing $\beta$-secretase in an $\mathrm{AD}$ mouse model. Thus, PGC-1 $\alpha$ might also be responsible for the $\beta$-secretaserelated reduction of $A \beta 40$ levels after treatment with $\mathrm{MH} 84$ in brains of Thy1-A $\beta \mathrm{PP}_{\mathrm{SL}}$. However, in our study MH84 did not reverse enhanced BACE1 mRNA levels in brains of Thy1-A $\beta P_{S L}$ mice. On the other site, PGC- $1 \alpha$ overexpression was reported to exacerbate $A \beta$ and tau deposition in another transgenic mouse model of AD [65].

BDNF represents one of the most widely distributed and extensively studied neurotrophins in the mammalian brain. Its functions include developmental processes, regulation of synaptogenesis, and neuroprotection [66]. Decreased BDNF levels have been determined in brains of AD patients [67] and reduced expression of BDNF has been related to reduced PGC- $1 \alpha$ levels in a mouse model of AD [47]. We report a significant downregulation of BDNF levels in brains of in brains of Thy-1 $\mathrm{A} \beta \mathrm{PP}_{\mathrm{SL}}$ mice, which was reversed after treatment with MH84. Thus, effects of MH84 might at least partly be related to enhanced BDNF expression although synaptic marker proteins were not changed.

\section{Conclusion}

MH84 represents a dual $\gamma$-secretase/PPAR $\gamma$ modulator that improves mitochondrial dysfunction by enhancing mitochondrial dysfunction via a PGC- $1 \alpha$-dependent mechanism. Thus, MH84 seems to be a new promising therapeutic agent with approved in-vivo activity for the treatment of $\mathrm{AD}$ that could help to modify the disease progression in early stages.

\section{Additional files}

Additional file 1: Figure S1. Representative NMR spectra of MH84 used for the current study. For analytical details please refer to [12]. (PDF 429 kb)

Additional file 2: Figure S2. Brain levels of the $\beta$-site of APP cleaving enzyme (BACE-1) mRNA. Expression levels of mRNA were normalized to PGK1 and B2M mRNA expression. Animals belonged to three different

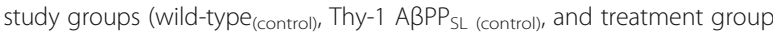
Thy-1 ABPP $S L(M H 84)$ ). Data represent means \pm SEM. $N=11$ (six females, five males); one-way ANOVA with Tukey's multiple comparison post test $\left({ }^{* *} p<0.01\right.$, against wild-type $\left.{ }_{(\text {control })}\right)$. (TIFF $562 \mathrm{~kb}$ )

Additional file 3: Figure S3. Western blot analysis of A brain-derived neurotrophic factor (BDNF), B Growth associated protein 43 (GAP43), and C synaptophysin in brain homogenate isolated from wild-type mice (control), Thy-1 ABPP SL (control), and MH-84-treated Thy-1 AßPP SL (MH84) mice. Tubulin $(\mathrm{A}, \mathrm{C})$ and GAPDH (B) were used as loading controls. Data represent means \pm SEM. $N=11$ (six females, five males); one-way ANOVA with

Tukey's multiple comparison post test $\left({ }^{* * *} p<0.001,{ }^{* *} p<0.01\right.$, against

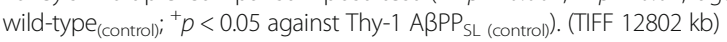

\section{Acknowledgements}

The help of Martina Piekorz who acted as animal caretaker is highly acknowledged.

\section{Funding}

This work was funded by the Doktor Robert-Pfleger Foundation and the Heinrich Sauer and Josef Schmidt Foundation.

\section{Availability of data and materials}

The datasets used and/or analyzed during the current study are available from the corresponding author on reasonable request.

\section{Authors' contributions}

MPo was involved in most of the experiments and guided AJ, SHE, and DB. $\mathrm{AJ}, \mathrm{SHE}$, and DB were responsible for western blotting, ELISA analysis, and qRT-PCR. HA, SHE, MPe, and MR were involved in the animal studies and measured mitochondrial function. MW and MS-Z supervised part of the work and were responsible for statistics. MS-Z and GPE as PIs oversaw the whole work. MP generated the figures. GPE wrote the manuscript. All authors read and approved the final manuscript.

Ethics approval and consent to participate

The protocol for the animal feeding study and tissue collection was approved by the local authorities for animal welfare (Regierungspraesidium Darmstadt, approval no. FU_K_5003). All experiments were carried out according to the European Communities Council Directive (86/609/EEC) by individuals with appropriate training.

Consent for publication

Not applicable.

Competing interests

The authors declare that they have no competing interests.

\section{Publisher's Note}

Springer Nature remains neutral with regard to jurisdictional claims in published maps and institutional affiliations. 


\section{Author details}

${ }^{1}$ Institute of Pharmacology, Goethe University, Frankfurt, Germany. ${ }^{2}$ Institute of Pharmaceutical Chemistry, Goethe University, Frankfurt, Germany.

${ }^{3}$ Institute of Nutritional Sciences, Justus-Liebig-University, Giessen, Germany.

\section{Received: 21 August 2017 Accepted: 12 January 2018}

\section{Published online: 13 February 2018}

\section{References}

1. Gardner RC, Valcour V, Yaffe K. Dementia in the oldest old: a multi-factorial and growing public health issue. Alzheimers Res Ther. 2013;5:27.

2. Querfurth HW, LaFerla FM. Alzheimer's disease. N Engl J Med. 2010;362:329-44.

3. Citron M. Alzheimer's disease: strategies for disease modification. Nat Rev Drug Discov. 2010;9:387-98.

4. Tan CC, Yu JT, Wang HF, Tan MS, Meng XF, Wang C, et al. Efficacy and safety of donepezil, galantamine, rivastigmine, and memantine for the treatment of Alzheimer's disease: a systematic review and meta-analysis. J Alzheimers Dis. 2014;41:615-31.

5. Guzior N, Wieckowska A, Panek D, Malawska B. Recent development of multifunctional agents as potential drug candidates for the treatment of Alzheimer's disease. Curr Med Chem. 2015;22:373-404.

6. Cummings J, Aisen PS, DuBois B, Frolich L, Jack Jr CR, Jones RW, et al, Drug development in Alzheimer's disease: the path to 2025. Alzheimer Res. 2016;8:39.

7. Rozemuller JM, Eikelenboom P, Stam FC, Beyreuther K, Masters CL. A4 protein in Alzheimer's disease: primary and secondary cellular events in extracellular amyloid deposition. J Neuropathol Exp Neurol. 1989;48:674-91.

8. Selkoe DJ, Abraham C, Ihara Y. Alzheimer-disease-insolubility of paired helical filaments (Phf) and the potential role of enzymatic cross-linking Neurology. 1982;32:A227.

9. Selkoe DJ, Yamazaki T, Citron M, Podlisny MB, Koo EH, Teplow DB, et al. The role of APP processing and trafficking pathways in the formation of amyloid beta-protein. Ann N Y Acad Sci. 1996:777:57-64.

10. Mikulca JA, Nguyen V, Gajdosik DA, Teklu SG, Giunta EA, Lessa EA, et al. Potential novel targets for Alzheimer pharmacotherapy: II. Update on secretase inhibitors and related approaches. J Clin Pharm Ther. 2013;39:25-37.

11. Landreth $\mathrm{G}$, Jiang Q, Mandrekar S, Heneka M. PPARgamma agonists as therapeutics for the treatment of Alzheimer's disease. Neurotherapeutics. 2008:5:481-9.

12. Hieke M, Ness J, Steri R, Dittrich M, Greiner C, Werz O, et al. Design, synthesis, and biological evaluation of a novel class of gamma-secretase modulators with PPARgamma activity. J Med. 2010;53:4691-700.

13. Moutinho M, Landreth GE. Therapeutic potential of nuclear receptor agonists in Alzheimer's disease. J Lipid Res. 2017:58:1937-49.

14. Sato T, Hanyu H, Hirao K, Kanetaka H, Sakurai H, Iwamoto T. Efficacy of PPAR-gamma agonist pioglitazone in mild Alzheimer disease. Neurobio Aging. 2011;32:1626-33.

15. Watson GS, Cholerton BA, Reger MA, Baker LD, Plymate SR, Asthana S, et al. Preserved cognition in patients with early Alzheimer disease and amnestic mild cognitive impairment during treatment with rosiglitazone: a preliminary study. Am J Geriatr Psychiatry. 2005;13:950-8.

16. Gold M, Alderton C, Zvartau-Hind M, Egginton S, Saunders AM, Irizarry M, et al. Rosiglitazone monotherapy in mild-to-moderate Alzheimer's disease: results from a randomized, double-blind, placebo-controlled phase III study. Dement Geriatr Cogn Disord. 2010;30:131-46.

17. Camacho IE, Serneels L, Spittaels K, Merchiers P, Dominguez D, De SB. Peroxisome-proliferator-activated receptor gamma induces a clearance mechanism for the amyloid-beta peptide. J Neurosci. 2004;24:10908-17.

18. Sastre M, Dewachter I, Rossner S, Bogdanovic N, Rosen E, Borghgraef $P$, et al. Nonsteroidal anti-inflammatory drugs repress beta-secretase gene promoter activity by the activation of PPARgamma. Proc Natl Acad Sci U S A. 2006;103:443-8.

19. Katsouri L, Parr C, Bogdanovic N, Willem M, Sastre M. PPARy co-activator-1a (PGC-1a) reduces amyloid- $\beta$ generation through a PPARy-dependent mechanism. J Alzheimers Dis. 2011;25:151-62.

20. Sauerbeck A, Gao J, Readnower R, Liu M, Pauly JR, Bing G, et al. Pioglitazone attenuates mitochondrial dysfunction, cognitive impairment, cortical tissue loss, and inflammation following traumatic brain injury. Exp Neurol. 2011; 227:128-35.

21. Chiang MC, Chern Y, Huang RN. PPARgamma rescue of the mitochondrial dysfunction in Huntington's disease. Neurobiol Dis. 2012;45:322-8.
22. Muller WE, Eckert A, Kurz C, Eckert GP, Leuner K, Müller WE, et al. Mitochondrial dysfunction: common final pathway in brain aging and Alzheimer's disease — therapeutic aspects. Mol Neurobiol. 2010;41:159-71.

23. Swerdlow RH, Khan SM. The Alzheimer's disease mitochondrial cascade hypothesis: an update. Exp Neurol. 2009;218:308-15.

24. Schuh RA, Jackson KC, Schlappal AE, Spangenburg EE, Ward CW, Park JH, et al. Mitochondrial oxygen consumption deficits in skeletal muscle isolated from an Alzheimer's disease-relevant murine model. BMC Neurosci. 2014;15:24

25. Picone P, Nuzzo D, Caruana L, Scafidi V, Di Carlo M. Mitochondrial dysfunction: different routes to Alzheimer's disease therapy. Oxid Med Cell Longev. 2014;2014:780179.

26. Friedland-Leuner K, Stockburger C, Denzer I, Eckert GP, Muller WE. Mitochondrial dysfunction: cause and consequence of Alzheimer's disease. Prog Mol Biol Transl Sci. 2014;127:183-210.

27. Leuner $\mathrm{K}$, Muller WE, Reichert AS. From mitochondrial dysfunction to amyloid beta formation: novel insights into the pathogenesis of Alzheimer's disease. Mol Neurobiol. 2012;46:186-93.

28. Swerdlow RH, Burns JM, Khan SM. The Alzheimer's disease mitochondrial cascade hypothesis: progress and perspectives. BBA - Mol Basis Dis. 2014; 1842:1219-31.

29. Swerdlow RH, Khan SM. A "mitochondrial cascade hypothesis" for sporadic Alzheimer's disease. Med Hypotheses. 2004;63:8-20.

30. Swerdlow RH. Mitochondria and mitochondrial cascades in Alzheimer's disease. J Alzheimers Dis. 2017; in press. https://doi.org/10.3233/JAD-170585.

31. Lin J, Wu H, Tarr PT, Zhang CY, Wu Z, Boss O, et al. Transcriptional coactivator PGC-1 alpha drives the formation of slow-twitch muscle fibres. Nature. 2002:418:797-801.

32. Sweeney G, Song J, Prince M, Bryce R, Albanese E, Wimo A, et al. The association between PGC-1a and Alzheimer's disease. Anat Cell Biol. 2016:49:1-6.

33. Qin W, Haroutunian V, Katsel P, Cardozo CP, Ho L, Buxbaum JD, et al. PGC 1a expression decreases in the Alzheimer disease brain as a function of dementia. Arch Neurol. 2009:66:352-61.

34. Flesch D, Ness J, Lamers C, Dehm F, Popella S, Steri R, et al. SAR-studies of gamma-secretase modulators with PPARgamma-agonistic and 5lipoxygenase-inhibitory activity for Alzheimer's disease. Bioorg Med Chem Lett. 2015:25:841-6.

35. Pellowska M, Stein C, Pohland M, Merk D, Klein J, Eckert GP, et al. Pharmacokinetic properties of MH84, a $\gamma$-secretase modulator with PPARy agonistic activity. J Pharm Biomed Anal. 2015;102:417-24.

36. Pohland M, Hagl S, Pellowska M, Wurglics M, Schubert-Zsilavecz M, Eckert GP. MH84: a novel $\gamma$-secretase modulator/PPARy agonist-improves mitochondrial dysfunction in a cellular model of Alzheimer's disease. Neurochem Res. 2016:41:231-42.

37. Hauptmann S, Scherping I, Drose S, Brandt U, Schulz KL, Jendrach M, et al. Mitochondrial dysfunction: an early event in Alzheimer pathology accumulates with age in AD transgenic mice. Neurobiol Aging. 2009;30: 1574-86.

38. Doert A, Pilatus U, Zanella F, Müller WE, Eckert GP. ${ }^{1} \mathrm{H}$ - and ${ }^{13} \mathrm{C}-\mathrm{NMR}$ spectroscopy of Thy-1-APPSL mice brain extracts indicates metabolic changes in Alzheimer's disease. J Neural Transm. 2015;122:541-50.

39. Blanchard V, Moussaoui S, Czech C, Touchet N, Bonici B, Planche M, et al. Time sequence of maturation of dystrophic neurites associated with $A$ beta deposits in APP/PS1 transgenic mice. Exp Neurol. 2003;184:247-63.

40. Hagl S, Berressem D, Grewal R, Sus N, Frank J, Eckert GP. Rice bran extract improves mitochondrial dysfunction in brains of aged NMRI mice. Nutr Neurosci. 2016;19:1-10.

41. Krumschnabel G, Fontana-Ayoub M, Sumbalova Z, Heidler J, Gauper K Fasching $M$, et al. Simultaneous high-resolution measurement of mitochondrial respiration and hydrogen peroxide production. Mitochondrial Med. 2015:1264:245-61.

42. Hagl S, Grewal R, Ciobanu I, Helal A, Khayyal MT, Müller WE, et al. Rice bran extract compensates mitochondrial dysfunction in a cellular model of early Alzheimer's disease. J Alzheimers Dis. 2015;43:927-38.

43. Boda E, Pini A, Hoxha E, Parolisi R, Tempia F. Selection of reference genes for quantitative real-time RT-PCR studies in mouse brain. J Mol Neurosci. 2009:37:238-53.

44. Larsen S, Nielsen J, Hansen CN, Nielsen LB, Wibrand F, Stride N, et al. Biomarkers of mitochondrial content in skeletal muscle of healthy young human subjects. J Physiol. 2012;590:3349-60. 
45. Leuner K, Schütt T, Kurz C, Eckert SH, Schiller C, Occhipinti A, et al. Mitochondrion-derived reactive oxygen species lead to enhanced amyloid beta formation. Antioxid Redox Signal. 2012;16:1421-33.

46. Eckert SH, Eckmann J, Renner K, Eckert GP, Leuner K, Müller WE. Dimebon ameliorates amyloid- $\beta$ induced impairments of mitochondrial form and function. J Alzheimers Dis. 2012;31:21-32.

47. Xia D-Y, Huang X, Bi C-F, Mao L-L, Peng L-J, Qian H-R. PGC-1a or FNDC5 is involved in modulating the effects of $A \beta 1-42$ oligomers on suppressing the expression of BDNF, a beneficial factor for inhibiting neuronal apoptosis, $A \beta$ deposition and cognitive decline of APP/PS1 Tg mice. Front Aging Neurosci. 2017;9:505.

48. Anandatheerthavarada HK, Biswas G, Robin MA, Avadhani NG. Mitochondrial targeting and a novel transmembrane arrest of Alzheimer's amyloid precursor protein impairs mitochondrial function in neuronal cells. J Cell Biol. 2003;161:41-54.

49. Reddy PH, Beal MF. Amyloid beta, mitochondrial dysfunction and synaptic damage: implications for cognitive decline in aging and Alzheimer's disease. Trends Mol Med. 2008;14:45-53.

50. Wilkins HM, Swerdlow RH. Amyloid precursor protein processing and bioenergetics. Brain Res Bull. 2017;133:71-9.

51. Schaefer PM, von Einem B, Walther P, Calzia E, von Arnim CA. Metabolic characterization of intact cells reveals intracellular amyloid beta but not its precursor protein to reduce mitochondrial respiration. PLoS One. 2016;11: e0168157.

52. Pera M, Larrea D, Guardia-Laguarta C, Montesinos J, Velasco KR, Agrawal RR, et al. Increased localization of APP-C99 in mitochondria-associated ER membranes causes mitochondrial dysfunction in Alzheimer disease. EMBO J. 2017:36:3356-71

53. Robinson A, Grösgen S, Mett J, Zimmer VC, Haupenthal VJ, Hundsdörfer B, et al. Upregulation of PGC-1a expression by Alzheimer's disease-associated pathway: presenilin 1/amyloid precursor protein (APP)/intracellular domain of APP. Aging Cell. 2014;13:263-72.

54. Pedrós I, Petrov D, Allgaier M, Sureda F, Barroso E, Beas-Zarate C, et al. Early alterations in energy metabolism in the hippocampus of APPswe/ PS1dE9 mouse model of Alzheimer's disease. BBA - Mol Basis Dis. 2014; 1842:1556-66.

55. Austin S, St-Pierre J. PGC1a and mitochondrial metabolism-emerging concepts and relevance in ageing and neurodegenerative disorders. J Cell Sci. 2012;125:4963-71.

56. Handschin C, Spiegelman BM. Peroxisome proliferator-activated receptor gamma coactivator 1 coactivators, energy homeostasis, and metabolism. Endocr Rev. 2006;27:728-35.

57. Calkins MJ, Manczak M, Mao P, Shirendeb U, Reddy PH. Impaired mitochondrial biogenesis, defective axonal transport of mitochondria, abnormal mitochondrial dynamics and synaptic degeneration in a mouse model of Alzheimer's disease. Hum Mol Genet. 2011;20:4515-29.

58. Larson SB, Day JS, Nguyen C, Cudney R, McPherson A. Structure of pig heart citrate synthase at 1.78 A resolution. Acta Crystallogr Sect F: Struct Biol Cryst Commun. 2009;65:430-4

59. Ronnback A, Pavlov PF, Mansory M, Gonze P, Marliere N, Winblad B, et al. Mitochondrial dysfunction in a transgenic mouse model expressing human amyloid precursor protein (APP) with the Arctic mutation. J Neurochem. 2016;136:497-502

60. Zhang C, Rissman RA, Feng J. Characterization of ATP alternations in an Alzheimer's disease transgenic mouse model. J Alzheimers Dis. 2015:44:375-8.

61. Monteiro-Cardoso VF, Oliveira MM, Melo T, Domingues MRM, Moreira PI, Ferreiro $\mathrm{E}$, et al. Cardiolipin profile changes are associated to the early synaptic mitochondrial dysfunction in Alzheimer's disease. J Alzheimers Dis. 2015;43:1375-92

62. Hieke M, Ness J, Steri R, Greiner C, Werz O, Schubert-Zsilavecz M, et al. SAR studies of acidic dual $\gamma$-secretase/PPARy modulators. Bioorg Med Chem. 2011;19:5372-82

63. Pendergrass W, Wolf N, Poot M. Efficacy of MitoTracker Green and CMXrosamine to measure changes in mitochondrial membrane potentials in living cells and tissues. Cytom A. 2004;61:162-9.

64. Katsouri L, Lim YM, Blondrath K, Eleftheriadou I, Lombardero L, Birch AM, et al. PPAR $\gamma$-coactivator-1a gene transfer reduces neuronal loss and amyloid- $\beta$ generation by reducing $\beta$-secretase in an Alzheimer's disease model. Proc Natl Acad Sci U S A. 2016;113:12292-7.
65. Dumont M, Stack C, Elipenahli C, Jainuddin S, Launay N, Gerges M, et al. PGC-1a overexpression exacerbates $\beta$-amyloid and tau deposition in a transgenic mouse model of Alzheimer's disease. FASEB J. 2014;28:1745-55.

66. Kowiański P, Lietzau G, Czuba E, et al. Cell Mol Neurobiol. 2017. https://doi.org/10.1007/s10571-017-0510-4.

67. Diniz BS, Teixeira AL. Brain-derived neurotrophic factor and Alzheimer's disease: physiopathology and beyond. NeuroMolecular Med. 2011;13:217-22

\section{Submit your next manuscript to BioMed Central and we will help you at every step:}

- We accept pre-submission inquiries

- Our selector tool helps you to find the most relevant journal

- We provide round the clock customer support

- Convenient online submission

- Thorough peer review

- Inclusion in PubMed and all major indexing services

- Maximum visibility for your research

Submit your manuscript at www.biomedcentral.com/submit 